\title{
AAAprawda. Telemetria prawdy
}

\begin{abstract}
Developed societies are not interested in the truth. The demand for truth has disappeared while its causal role has been marginalized and limited to the authentication of identity in banking systems and social media. Exactly a century earlier, due to due to fallibilism or falsificationism, science rejected the Cartesian conception of Absolute truth, while retaining its objectivity although not the stability of its findings. Today, we intersecting worlds, but not identical in values. The reason for this is not the inability to work out a common research method but an axiological redefinition, which often comes down to the question: truth and so what?
\end{abstract}

Keywords: truth, illusion, semiosphere, Internet

\section{Wprowadzenie}

Drawda jest wartością uniwersalną w kulturze Zachodu na tyle, że dążenie do niej przez wieki kształtowało etos nauki i naukowców, a co za tym idzie, wpływało na funkcjonowanie społeczeństw i poszczególnych obywateli. Prawdziwe jest istniejące, racjonalne, piękne, dobre, użyteczne. Do prawdy zmierzano, nie licząc się z kosztami, poczynając od wzniosłego celu wiedzy prawdziwej jako wartości autotelicznej, do prawdy jako oręża wyzwolenia społeczeństw spod tyranii i ciemnoty. Umierano za i w imię prawdy, była na podobieństwo słońca, drogą do oświecenia i zbawienia. W wymiarze osobistym umiejętność prawdziwej oceny sytuacji od zawsze wydawała się zwiększać skuteczność działania, dając nam 
pragmatyczną przewagę nad błądzącymi w fałszu i niewiedzy. Żywimy te poglądy, które uważamy za prawdziwe, a jeśli nawet propagujemy nieprawdę i robimy to umyślnie, to dopuszczamy się godnego potępienia kłamstwa. Czy jednak w drugiej dekadzie XXI wieku dążenie do prawdy oznacza to samo, co znaczyło u zarania naszej nauki i kultury, obowiązując w praktycznie niezmienionej formie przez ponad dwadzieścia wieków? Konkretna wiedza, szczególnie empiryczna, którą w różnych okresach historycznych uważano za prawdę, zwykle nie przechodziła podstawowego kryterium prawdy, czyli niezmienności w czasie. Dziś temporalność ustaleń nauk empirycznych bywa postrzegana jako cnota i konfrontowana z naukami humanistycznymi, które wyglądają jakby już dawno zatrzymały się w pogoni za prawdą i doskonałością metodologiczną. U podstawy leży przekonanie, że to, co nowe i zastępujące stare, musi być lepsze, nawet w nauce. Współczesna wiedza empiryczna staje się anachroniczna w tempie porównywalnym do wizerunkowo-modowego starzenia się nowych technologii, np. telefonów komórkowych, a adepci wszelakich uczelni niehumanistycznych mają wątpliwości, czy sięgać do artykułów starszych niż pięcioletnie. Co w takim razie stało się z pierwotnym celem nauki i poznania, czyli dążeniem do wiedzy praw dzi w ej? Czy prawda dalej jest prawdą, a może pod tym pojęciem kryje się już zupełnie coś innego niż jeszcze na początku XX wieku? Dzisiaj, poza wąskimi grupami naukowców, prawie nikomu nie zależy na prawdzie, chyba że w ten sposób określimy niezwykle cenną wiedzę, którą komercyjne podmioty starają się pozyskać od konsumenta, czujnie obserwując jego ruchy w rzeczywistości już nieanalogowej ${ }^{1}$, ale alternatywnej, cyfrowej, która ma tę przewagę nad pierwszą, że w pełni poddaje się parametryzacji.

W prezentowanym artykule stawiam hipotezę, że prawda jest coraz mniej rozpoznawana w przestrzeni medialnej i społecznej i tym samym traci na znaczeniu jako wartość uniwersalna. Prawdziwe staje się to, co przynosi założony efekt. Jednak to nie z prawdziwej wiedzy o świecie wynika oczekiwany skutek działania, tylko z dostosowania, podciągnięcia rzeczywistości do oczekiwanego skutku - wykreowana przez nas prawda o świecie staje się jego budulcem dzięki narzędziom cyfrowej kreacji. Jest to realizowane środkami oferowanymi przez tzw. semiosferę², której ucieleśnieniem jest Internet, stopniowo zastępujący, np. poprzez media społecznościowe, świat rzeczywisty i jego obraz. O ile w nauce prawda zachowała swój w miarę tradycyjny charakter, o tyle o jej wartości naukowej decyduje parametryzacja wyników badań, gromadzonych w internetowych bazach danych.

${ }^{1}$ W artykule używam terminu „rzeczywistość analogowa”, rozumiejąc przez to całość tego, co do ery powszechnej cyfryzacji, czyli początku XXI wieku, uchodziło za tzw. świat realny, empiryczny, zmysłowy, a co ważniejsze, za niezależny w swoim istnieniu od woli istot ludzkich.

${ }^{2}$ Szerzej zob. T. Michaluk, Czy prawda jest reprezentacjq w cyfrowej semiosferze (Internecie)? Podstawy metodologiczne w badaniach fenomenu semiosfery, „Studia Philosophica Wratislaviensia” 7(4)/2012. 


\section{Prawda}

Poważna i świadoma metodologicznie nauka empiryczna od czasów Peirce`owskiej koncepcji fallibilizmu ${ }^{3}$ czy też jej bardziej znanej Popperowskiej ${ }^{4}$ odmiany falsyfikacjonizmu ${ }^{5}$ traktuje prawdę podobnie do przechodniego pucharu w sporcie kwalifikowanym - uznanie za prawdę nie oznacza bycia prawdą raz na zawsze ani nawet w ogóle bycia nią, a jedynie, że w danym momencie nikt nie opublikował doniesień z badań, które podważałyby nasze ustalenia ${ }^{6}$. Powyższe stwierdzenie dotyczy tzw. nauki normlanej w znaczeniu normalności, które nauce nadał Thomas S. $\mathrm{Kuhn}^{7}$. Tego typu aktywnością naukowcy przede wszystkim rozwiązują łamigłówki (wiedzą, gdzie chcą dotrzeć i tam w końcu docierają), a nie dokonują przełomowych odkryć, tym bardziej rewolucji, chcąc pozostać w bezpiecznym głównym nurcie nauki, który jest wysoko punktowany. Zasady i reguły metodologiczne prowadzenia badań zwykle nie podlegają kontestacji, a naukowcy i wydawcy ich artykułów, starają się uniknąć odkrywania anomalii, które godzą w dobrze ugruntowany paradygmat danej dziedziny, obowiązujący w określonym momencie historycznym. Określenie „sport kwalifikowany”, w odniesieniu do nauki normalnej, nie padło tu przypadkiem, ponieważ najważniejszym formalnym kryterium prawdy nie jest prawdziwe odniesienie do bytu, o którym wyrażany jest sąd, np. z obszaru rzeczywistości analogowej, ale miejsce i forma publikacji. W dobie globalnej sieci internetowej oplatającej kulę ziemską możliwa jest sytuacja, w której mało znany naukowiec z tzw. Południa odkrywa prawdę w swoim lokalnym języku, jednak nie zostanie to nawet zauważone przez społeczność badawczą, skoncentrowaną wokół rankingowanych (kwalifikowanych) globalnie anglojęzycznych periodyków i ośrodków, które są ich wydawcami. Podobnie w sporcie - może żyje gdzieś biegacz, który na dystansie 100 m jest niedościgniony, jednak jeśli nie występuje w zawodach, których wyniki są uznawane przez związki sportowe, to jego dokonania pozostaną nieznane i zapomniane. Laur najlepszego, zarówno w jednym jak

${ }^{3}$, „...] są trzy rzeczy co do których nie ma nadziei, że możemy je osiągnąć na drodze rozumowania, mianowicie, absolutna pewność (certanity), absolutna dokładność (exactitude), absolutna powszechność (universality)” (CP 1.141 do 175). C.S. Peirce, Collected Papers of Charles Sanders Peirce, vols I-VIII, Harvard University Press, Cambridge 1931-1935, 1958. Zob. też: C.S. Peirce, The Essential Peirce: Selected Philosophical Writings, vol. I-II, Indiana University Press, Bloomington \& Indianapolis 1998.

${ }^{4}$ K.R. Popper, Logika odkrycia naukowego, Wydawnictwo Naukowe PWN, Warszawa 2002.

5 Szerzej o analizie współczesnych odmian falsyfikacjonizmu zob. A. Grobler, Metodologia nauk, Aureus/Znak, Kraków 2006, s. 61 nn.

6 Rynek wydawniczy stwarza określone wymagania autorom, jak choćby konieczność wpisania się w już istniejące badania naukowe. Wymóg tego typu wydaje się w istotnym stopniu wynikać ze sposobów rankingowania czasopism i wydawnictw.

7 T.S. Kuhn, Struktura rewolucji naukowych, Wydawnictwo Aletheia, Warszawa 2011. 
i drugim przypadku, otrzyma ten, którego odpowiednio sklasyfikowany wynik trafił do skomercjalizowanego systemu dystrybucji wiedzy kontrolowanego przez wydawców (nauka) lub działaczy (sport). I w nauce, i w sporcie są dyscypliny mniej lub bardziej popularne czy też w różnym stopniu przyciągające środki finansowe, a podstawą rankingów w nauce jest parametryzacja, czyli liczbowe przewalutowanie wyników nauki.

Czy zatem w ogóle jest sens w dążeniu do podstawowej jeszcze w XIX wieku wartości etosu naukowca ${ }^{8}$, czyli autotelicznie rozumianej prawdy? Z perspektywy historycznej nie ulega wątpliwości, że w nauce kształtowanej przez kulturę śródziemnomorską prawda istnieje i jest jedną z wartości podstawowych, ale musi być odkrywana i interpretowana. Sekstus Empiryk, referujący stoicką koncepcję znaków, w następujący sposób to przedstawiał:

[...] są więc cztery rodzaje rzeczy: pierwszy rzeczy oczywistych [...], drugi raz na zawsze niejawnych, trzeci niejawnych z natury, a czwarty chwilowo [niejawnych] powiemy, że nie każdy rodzaj rzeczy, lecz tylko niektóre potrzebują oznaki. Rzecz jasna, nie dopuszczają oznaki ani rzeczy raz na zawsze niejawne, ani te, które są oczywiste, ponieważ same przez się podpadają pod spostrzeżenia i żadnej innej rzeczy nie potrzebują do dania [o sobie] informacji $[\ldots]^{9}$.

Nie dość, że prawda wymaga trudu w jej odkryciu, być może poza rzekomą oczywistą naocznością, która nie budziła uzasadnionych wątpliwości w czasach Empiryka, to jeszcze bywa celowo ukrywana. Przekonuje nas o tym Giovanni Reale, według którego Platon od początku swej drogi, tzn. jeszcze przed powstaniem dialogów, miał intencję ukrycia prawdy pod postacią tzw. nauk niepisanych, które zostały przekazane ustnie tylko wtajemniczonym, a nie zostały przedstawione w słynnych dialogach i dopiero „drugie żeglowanie” może nas do prawdy zbliżyć ${ }^{10}$. Dwa powyższe przykłady ze starożytności, i nie zmieniło się to do dnia dzisiejszego, uzmysławiają, że prawdy jako rzeczy samej w sobie nie sposób poznać (poza problematyczną naocznością, o czym w dalszej części artykułu). Prawda musi mieć swoją reprezentację i w tym sensie może być elementem relacji, w której jawne dla nas są inne elementy, np. sąd wyrażony w zdaniu (utrwalonym i podlegającym pod zmysły), który może być prawdziwy, ponieważ jest częścią relacji, której jednym z elementów jest prawda (reprezentacja wieloelementowa), lub zachodzącą relację określimy jako prawdziwościową (reprezentacja diadyczna). Prawda jest ukryta, ale czym w ujęciu tradycyjnym (analogowym) jest prawda? W najbardziej intuicyjnym i ogólnym rozumieniu prawda jest zgodnością naszych myśli z jakimś

${ }^{8}$ Por. S. Amsterdamski, Tertium non datur?, Wydawnictwo Naukowe PWN, Warszawa 1994.

${ }^{9}$ Sekstus Empiryk, Przeciw logikom, w: I. Dąbska, Wprowadzenie do starożytnej semiotyki greckiej. Studia i teksty, Polskie Towarzystwo Semiotyczne, Ossolineum, Wrocław 1984, ss. 98-99.

${ }^{10}$ G. Reale, Historia filozofii starożytnej, t. 2: Platon i Arystoteles, RW KUL Lublin 1997. 
elementem (stanem) świata empirycznego. W tym sensie, jeśli o czymś orzekamy i to istnieje, to orzekamy prawdziwie.

Twierdzić o Bycie, że nie istnieje, albo o Nie-Bycie, że istnieje, jest fałszem; natomiast twierdzić, że Byt istnieje, a Nie-Byt nie istnieje, jest prawdą; tak że kto twierdzi o czymś, że istnieje albo że nie istnieje, powie pradę albo fałsz ${ }^{11}$.

Powyższa, korespondencyjna definicja prawdy jest być może najbardziej znana w filozofii, nauce i była wielokrotnie rozwijana, modyfikowana, jak również poddawana uzasadnionej krytyce. Wybitny polski logik Alfred Tarski, wychodząc od krytycznej analizy definicji Arystotelesa, zaproponował semantyczną koncepcję prawdy, do której według niego można sprowadzić inne definicje o podobnym charakterze i funkcjonalności:

[...] every definition of truth which is materially adequate would neccessarily be equivalent to that actually constructed. [...] In particular, we can prove with its help the laws of contradiction and of excluded middle, which are so characteristic of the Aristotelian conception of truth; i.e., we can show that one and only one of any two contradictory sentences is true ${ }^{12}$.

W szczególności definicja Tarskiego formułuje warunki prawdziwości zdań (sądów) opisujących rzeczywistość pozajęzykową i dzięki temu jest intuicyjnym wyborem dzisiejszych empirystów. Oczywiście nie twierdzę, że jest to wybór zły, wręcz przeciwnie, takie rozumienie prawdy było i jest skutecznym sposobem budowania ontologii świata dualistycznego, analogowo-inteligibilnego. Uważam jednak, że tego typu definicji wymyka się autonomiczna semiosfera, która wymaga odejścia od wszechobecnego w nauce (a tym samym i kulturze) dualizmu, który niekoniecznie jest jedyną czy też najlepszą drogą, do odkrycia prawdy ${ }^{13}$.

Przez ponad dwa tysiące lat społeczeństwa i wytwarzana przez nie nauka, a co istotniejsze kultura, nie widziały (i do tej pory często nie widzą) nic niepokojącego we wszelkich rodzajach dualizmów, który od zawsze jawi się jako uniwersalny klucz do prawdy. Warto zauważyć, że w XX wieku z dualizmem próbował mierzyć się postmodernizm, wyprowadzając atak w podstawę systemu dualistycznego, czyli Platona, jednak w zamian nie proponował nic oprócz pełnej dowolności interpretacyjnej. Dopiero pojawienie się cyfrowej i autonomicznej semiosfery dokonało istotnej zmiany.

11 Arystoteles, Metafizyka, PWN, Warszawa 1983, 1011b, patrz także 1051b.

12 A. Tarski, The semantic conception of truth and the foundations of semantics, „Philosophy and Phenomenological Research” 4(3)/1944, ss. 341-376. Polski przekład artykułu w: A. Tarski, Pisma logiczno-filozoficzne, t. I: Prawda, Wydawnictwo Naukowe PWN, Warszawa 1995.

13 „,...] dualizm, w jego najszerszym prawdziwym znaczeniu jako filozofii, przeprowadza swoje analizy siekierą, pozostawiając jako elementy ostateczne, niepowiązane kawałki istnienia, co jest najbardziej wrogie synechizmowi”. (CP 7.570). Tłum. - T.M. 


\section{Sceptycyzm}

Próby podważenia wiarygodności prawdy opartej na percepcji zmysłowej, powszechnie uznawanej przez przeciętnego człowieka, sięgają czasów sceptyków, przez nowożytny projekt prawdy absolutnej Kartezjusza, aż do XX-wiecznego dekonstrukcjonizmu i postmodernizmu ${ }^{14}$. Jednak prawda oczywista i powszechna była i jest oparta na zmyśle wzroku, a masowa w nią wiara ma się bardzo dobrze, przynajmniej jeśli chodzi o świat empiryczny. Śmiertelnik zwykle ma stosunek do swoich zmysłów podobny do stosunku sądu (instytucji) wobec podejrzanego. Dopóki wina nie zostanie zmysłom udowodniona, są one niewinne, ergo przedstawiają nam (domniemany) prawdziwy obraz rzeczywistości.

Sceptycyzm poznawczy, wyrażający się w różnym stopniu brakiem zaufania wobec zmysłów, jako źródła wiedzy prawdziwej o świecie, nie jest naturalną postawą epistemologiczną dla większości ludzi w codziennym funkcjonowaniu, w tym również naukowców. Klasyk nowożytnego sceptycyzmu, Kartezjusz, swoją krytykę zmysłów zaczyna od stosunkowo prostych sytuacji, w których możemy podlegać ułudzie, np. podczas snu, którego nie sposób odróżnić od jawy. Nawet jeśli uznamy, że zmysły są wiarygodne, to zawsze możemy być pod wpływem złego demona (genius malignus), przed którym nie sposób uciec nawet w matematyczne rozważania ${ }^{15}$. Jednak czy faktycznie Kartezjusz przedstawia sytuację w sposób wiarygodny, tzn. czy na podstawie owego wydumanego zagrożenia dla zmysłów rzeczywiście powinienem w nie zwątpić? Wbrew deklaracjom o zawieszeniu dotychczas zdobytej wiedzy (epoché), nie jest to prosta operacja umysłu, ponieważ tkwi w nas głębokie przekonanie o realności świata, z którego wielki filozof zapewne zdawał sobie sprawę. W konsekwencji sceptycyzm musi zostać przełamany, a prawdziwość świata jest gwarantowana przez Boga, istotę dobrą, która nie pozwala, by człowiek był permanentnie i celowo wprowadzany w błąd, szczególnie przekonaniem o istnieniu świata poza samą myślą. Jednak rozwój współczesnych technologii dał dodatkowy argument sceptykom, zapoczątkował nowy rodzaj ułudy, permanentną ułudę na życzenie, na trzeźwo, która w istocie jest świadomą i celową rezygnacją z prawdy ${ }^{16}$.

${ }^{14}$ Por. R. Rorty, Obiektywność, relatywizm i prawda, Fundacja Aletheia, Warszawa 1999.

${ }^{15}$ Kartezjusz (René Descartes), Medytacje o filozofii pierwszej, Zielona Sowa, Kraków 2005.

${ }^{16}$ Podobnie wygląda proces rezygnacji społeczeństw otwartych z wartości uważanych jeszcze kilkadziesiąt lat temu za fundamentalne dla ich efektywnego istnienia i rozwoju, czyli prywatności (braku inwigilacji) i swobody działania jednostki. 


\section{Sceptycyzm w erze semiosfery}

Współczesny człowiek nie szczędzi środków na to, żeby zostać oszukanym z własnej woli, tzn. z przekonaniem, że kontroluje sytuację i może się z niej wycofać w dowolnym momencie. Określane jest to mianem immersji, czyli wtopieniem się w ułudę (rzeczywistość nie-analogową), w którą wkraczamy. Dowodem na to mogą być coraz większe ekrany w kinach, rosnące przekątne domowych telewizorów, a w zasadzie tzw. kin domowych, i rozdzielczość generowanego na nich obrazu, która uniemożliwia zobaczenie gołym okiem składowych pikseli (technologia określana jako retina), czy rozwijająca się w entuzjastycznej atmosferze rzeczywistość rozszerzona i wirtualna (AR, VR). W praktyce na początku XXI wieku okazało się, że jest dokładnie odwrotnie niż chciał Kartezjusz, mający za cel ustalenie absolutnie niepodważalnej metody poznania prawdy, zyskania absolutnej pewności, że to, o czym myślimy, jest prawdziwe.

Dla dorastających obecnie pokoleń rzeczywistość analogowa (a-rzeczywistość) przestaje być główną domeną codziennej aktywności, tym samym prawda do niej odniesiona nie jest już tak bardzo pożądaną wartością jak w czasach przed powszechnością Internetu w krajach rozwiniętych. W kontekście aktywności na portalach społecznościowych, jakie ma znaczenie, czy patrząc na błękit nieba, chmury i drzewa, są one prawdziwe, czy nie? Klasyczna definicja prawdy Tarskiego nie tyle, że przestała być praw dziwa, ile stała się nieadekwatna do oczekiwań e-podmiotów funkcjonujących w nowej e-rzeczywistości. Zgodność prawdy z hipotetyczną rzeczywistością straciła na znaczeniu. Filozofia i nauka przez wieki dowodziły, że rzeczywistość jest sama w sobie nie do poznania, więc i tak jej nie poznamy w takim stopniu, w jakim możemy poznać wykreowaną przez nas internetową semiosferę, będącą w swojej istocie znakami i ich interpretacją.

Jednak cios dla empirystów nadszedł z nieoczekiwanej strony. Cóż z tego, że sam Demon Zwodziciel może nas wprowadzać w błąd, skoro nie ma na to dowodów, a w dodatku skutecznie działam w rzeczywistości, z którą wchodzę w interakcję, nawet jeśli jest ona fałszywa i/albo społecznościowa? To nie ja, jako podmiot poznający fenomeny przez wrażenia, mam obowiązek udowodnić swoją niewinność, ale wszelka ułuda ma odkryć swoją winę.

Pragmatycznie funkcjonującym kryterium prawdy jest zysk, skorelowany z liczbą polubień (likes) i udostępnień oraz pozycjonowaniem w wyszukiwarkach, szczególnie w społecznościowej części semiosfery, o czym doskonale wiedzą korporacje, a nawet przeciętny zjadacz mediów społecznościowych. Jest to prawda celowana, odkrywająca zależności w samej semiosferze, uogólniająca procesy nią rządzące. W tym kontekście np. dość jasne się staje, komu i czemu służą tzw. fake news, które jak na razie budzą zgrozę wśród osób niegdyś określanych jako starej daty. Fn - jako informacja - nie są niczym szczególnym w semiosferze, ponieważ 
dążą do kreacji wizji rzeczywistości w przestrzeni zbudowanej ze znaków i ich znaków interpretantów. Mają przekonywać i kreować rzeczywistość, a nie informować, a jeszcze mniej coś odkrywać w klasycznym sensie. Brakuje im prawdziwego odniesienia do analogowej rzeczywistości, która, jak staram się wykazać, straciła na znaczeniu, więc autorzy fn wydają się nią nie przejmować. Na razie znajdują się jeszcze osoby, którym zależy, na dowodzeniu fałszywości fn, czyli niezgodności z rzekomą a-rzeczywistością. Czy jednak odnosi to zamierzony pragmatyczny efekt, tzn. czy po dowiedzeniu braku zgodności tego, co zostało przedstawione w fake newsie z prawdą materialną, siła odziaływania fn znika, gdy tymczasem zdążył on utrwalić się już w tysiącach, o ile nie milionach odsłon na urządzeniach użytkowników indywidualnych? Nie. Brak zainteresowania demaskacją fn jest zjawiskiem zwykle mało istotnym, jednak nabiera wagi, gdy np. dotyczy historii.

\section{Prawda ekranu. Wstęga Möbiusa}

Wzrastające możliwości techniczne cyfrowego kreowania światów, w których rozgrywa się fabuła filmu, prowadzą do potencjalnie całkowitego zafałszowania przedstawianej rzeczywistości, a w zasadzie umożliwia wykreowanie pełnej quasi-realności. Widz, oglądając na ekranie cyfrowo (komputerowo) generowane dynamiczne sceny, nie dysponuje narzędziami badawczymi, które umożliwiłyby jednoznaczną ocenę, w jakim stopniu elementy danej lokacji podlegają prawom fizyki i wzajemnej interakcji, czyli w jakim stopniu są prawdziwe, dodajmy, w odniesieniu (relacji) do naszej obecnej wiedzy na temat praw natury. Jednak czy w ogóle jest tym zainteresowany, tzn. oceną prawdziwości tego, co ma we wrażeniach? Odkrycie możliwości cyfrowego wzbogacania scen w swoich początkach budziło powszechny i niemały zachwyt. Filmowcy prześcigali się w coraz to nowszych efektach, których rozwój i komplikacja były i są ściśle skorelowane z pojawianiem się kolejnych generacji maszyn cyfrowych i ich oprogramowania. Terminator 2: Dzień sqdu (Terminator 2: Judgment Day, 1991) przedstawił rewolucyjne efekty w postaci zmiennokształtnego robota zbudowanego z płynnego metalu (terminator model T-1000), przyjmującego na oczach widzów kształty ludzi i przedmiotów. T-1000 w praktyce nie miał ograniczeń i, dysponując swoistą sztuką mimetyczną, mógł się upodobnić do wszystkiego, czego dotknął, zresztą dokładnie tak, jak rzeczywistość generowana cyfrowo może przybierać dowolne kształty przed naszymi oczami. Przypuszczalnie Kartezjusz byłby zachwycony, niekoniecznie progresem w ułudzie, ale implikacjami metafizycznymi T-1000, ponieważ jedyne, czego nie mógł ów niezwykły robot, to zmniejszyć swojej całkowitej objętości i np. przybrać postaci pudełka zapałek, czyli dokładnie tak jak postulowana przez ojca racjonalizmu res extensa. Na początku lat 90. ubiegłego wieku sceny tego typu zapierały dech w piersiach miłośników gatunku SF. Jednak 
wystarczyła dekada, żeby nastąpiło wysycenie technologią, a dziełem, które jeszcze zachwycało krytyków odpowiednim zbalansowaniem rzeczywistości i wirtualności była trylogia filmowa Władca Pierścieni (The Lord of the Rings, 2001-2003). Obecnie nie ma filmu, a nawet sceny, potencjalnie niebędącej wytworem renderingu cyfrowego, który stał się tani i trafił pod strzechy. Spektrum możliwości zastosowania rzeczonych technologii rozpoczyna się od bajek, a kończy na filmach pretendujących do udawania świata analogowego i jego praw w wymiarze wizualnym i rzekomego następstwa zdarzeń, które wykorzystuje quasi-fizykę. Oglądając wyrenderowany film, można mieć uzasadnione wątpliwości, czy np. pocisk w rzeczywistości miałby szansę trafić w cel albo czy pojazd utrzymałby się na jezdni - wbrew pozorom jest to istotne i warunkuje rozwój fabuły, jednak nie do zweryfikowania przez widza przed ekranem.

Prawda w naszej kulturze to również p r o c e s dochodzenia do niej (Sokrates), który współcześnie przeistacza się w znaczeniową wstęgą Möbiusa. Kultowe seriale i ich kolejne sezony generują dziesiątki odcinków zmierzających donikąd, co wydaje się nie przeszkadzać ich konsumentom ${ }^{17}$, a utrzymanie wartkiego nurtu nadprodukcji wymaga wręcz powstawania komercyjnych kanałów dystrybucji, oczywiście również w semiosferze. Niegdysiejsze opery mydlane i sitkomy zostały zastąpione produkcjami (także wysokobudżetowymi), które są kontynuowane w nieskończoność i to nie dlatego, że żal inwestorom wyrzucić scenografię i kostiumy, ale najzwyczajniej nie ma już zapotrzebowania na konkluzję, na dopełniony w ostatnim odcinku przekaz, może poza lokowaniem produktu, o czym zresztą informowani są widzowie, i co w praktyce nic nie zmienia. Kolejne odcinki nie mają żadnego stosunku do prawdy, która nawet nie kryje się gdzieś poza całością (jak prawda u Platona), czego mógłby oczekiwać widz.

Być może dzisiejsza prawda najbardziej dramatycznie objawia przedmiotowe traktowanie jednostek w procesie ich uwiarygodniania na potrzeby cyfrowej semiosfery. Deklaracja osoby (podmiotu), nawet poparta stosownym analogowym dokumentem, staje się coraz mniej wiarygodna w internecie rzeczy (i podporządkowanych im pracowników), ocierając się o maszynowe lekceważenie. Zyskuje natomiast cielesność, która jednoznacznie może potwierdzi ć swoją tożsamość danymi biometrycznymi. Z podmiotowości zmierzamy wprost zatem w przedmiotowość, której nieomylność zagwarantują maszyny i algorytmy, de facto stając się sędziami sądów prawdziwych w odpowiedzi na pytanie: „Czy jesteś osobą, za którą się podajesz”?

${ }^{17}$ Zastrzegam, że nie dotyczy to serialu The Simpsons (emitowanego od 1989 do dnia powstania prezentowanego tekstu) i podobnych, w których każdy odcinek stanowi autonomiczną znaczeniowo całość, „wyraża” jakąś prawdę. 


\section{Wnioski}

Wydawać by się mogło, że obok trzech światów postulowanych przez Karla R. Poppera ${ }^{18}$ wyrasta w oszałamiającym tempie świat czwarty - autonomiczna semiosfera pod postacią Internetu. Tak nie jest. Cyfrowa semiosfera wchłania resztę światów, nawet ten pierwszy fizyczny, który jako niezależny od wrażeń i mniemań wydawał się być bezpieczny, stanowiąc solidny fundament ludzkiej wiedzy, działania i nauki. Kreowane cyfrowo fantazje wzorowane na świecie empirycznym dowiodły przeciętnemu konsumentowi, bez konieczności odwoływania się do filozofii i jej epistemologii, że nie można ufać zmysłom. Czy jednak słowo „dowiodły” jest adekwatne do sytuacji i czy brak zaufania do zmysłów powoduje niepokój? Nie, ponieważ wymagałoby to wcześniejszej chęci poszukiwania prawdy przez jednostkę. Prawda odnosząca się do świata empirycznego jest trudna do odkrycia, o ile w ogóle w ostateczności możliwa do ustalenia, w co wątpi współczesna metodologia nauki. Cyfrowa kreacja wydaje się bardziej atrakcyjna i co ważniejsze, powstaje na naszych warunkach, w celu zaspokojenia naszych potrzeb, skutecznie to czyniąc. Platon wyrzuciłby Internet z państwa.

\section{Literatura}

Amsterdamski S., Tertium non datur?, Wydawnictwo Naukowe PWN, Warszawa 1994.

Arystoteles, Metafizyka, PWN, Warszawa 1983.

Dąbska I., Wprowadzenie do starożytnej semiotyki greckiej. Studia i teksty, Polskie Towarzystwo Semiotyczne / Ossolineum, Wrocław 1984.

Grobler A., Metodologia nauk, Aureus/Znak, Kraków 2006.

Kartezjusz (René Descartes), Medytacje o filozofii pierwszej, Zielona Sowa, Kraków 2005. Khun T.S., Struktura rewolucji naukowych, Wydawnictwo Aletheia, Warszawa 2011.

Michaluk T., Czy prawda jest reprezentacja w cyfrowej semiosferze (Internecie)? Podstawy metodologiczne w badaniach fenomenu semiosfery, „Studia Philosophica Wratislaviensia” 7(4)/2012.

Peirce C.S., Collected Papers of Charles Sanders Peirce, vols I-VIII, Harvard University Press, Cambridge 1931-1935, 1958.

Peirce C.S., The Essential Peirce: Selected Philosophical Writings, vol. I-II, Indiana University Press, Bloomington \& Indianapolis 1998.

Popper K.R., Logika odkrycia naukowego, Wydawnictwo Naukowe PWN, Warszawa 2002.

Popper K.R., Wiedza obiektywna, Wydawnictwo Naukowe PWN, Warszawa 2019.

Reale G., Historia filozofii starożytnej, t. 2, RW KUL, Lublin 1997.

Rorty R., Obiektywność, relatywizm i prawda, Fundacja Aletheia, Warszawa 1999.

Tarski A., The semantic conception of truth and the foundations of semantics, „Philosophy and Phenomenological Research" 4(3)/1944.

Tarski A., Pisma logiczno-filozoficzne, t. I: Prawda, PWN, Warszawa 1995.

${ }^{18}$ Por. K.R. Popper, Wiedza obiektywna, Wydawnictwo Naukowe PWN, Warszawa 2019. 